Please do not remove this page

RMIT

UNIVERSITY

\title{
Transforming transport planning in the postpolitical era
}

Legacy, Crystal

https://researchrepository.rmit.edu.au/esploro/outputs/9921860290501341/filesAndLinks?institution=61RMIT_INST\&index=null

Legacy, C. (2015). Transforming transport planning in the postpolitical era. Urban Studies, 53(14), 3108-3124. https://doi.org/10.1177/0042098015602649

Document Version: Accepted Manuscript

Published Version: https://doi.org/10.1177/0042098015602649

Repository homepage: https://researchrepository.rmit.edu.au

(C) Urban Studies Journal Limited 2015

Downloaded On 2023/04/26 22:47:58 +1000

Please do not remove this page 
Thank you for downloading this document from the RMIT Research Repository.

The RMIT Research Repository is an open access database showcasing the research outputs of RMIT University researchers.

RMIT Research Repository: http://researchbank.rmit.edu.au/

\section{Citation:}

Legacy, C 2015, 'Transforming transport planning in the postpolitical era', Urban Studies, pp. 1-17.

See this record in the RMIT Research Repository at:

https://researchbank.rmit.edu.au/view/rmit:33566

Version: Accepted Manuscript

Copyright Statement: @ U Urban Studies Journal Limited 2015

Link to Published Version:

http://dx.doi.org/10.1177/0042098015602649

\section{PLEASE DO NOT REMOVE THIS PAGE}




\title{
Transforming transport planning in the postpolitical era
}

\section{Crystal Legacy}

\begin{abstract}
The aim of this paper is to examine how the postpolitical era of planning has created both binaries and intersections in the reimaging of transport futures and how the latter precipitates a redefinition of democratic transport prioritisation. Focusing particularly on the point in the transport planning process when urban transport priorities are identified, the paper explores how citizens respond to the inherently political, yet not always democratic, aspects of setting transport investment priorities. This relationship is investigated through a single case study of Melbourne, Australia where a 6 kilometre inner city road tunnel was deemed a 'done deal' by elected officials in the lead up to a state election, removing the controversial project from open public scrutiny. Drawing upon 15 semi-structured interviews with community campaigners opposing the proposed East West Link road tunnel, this analysis reveals how community-based groups and individual residents alike can evolve beyond NIMBY-focused agitation to garner a spatially dispersed re-politicisation of urban transport priorities. While the postpolitical framing of infrastructure delivery introduces a binary between state interventionist planning and citizen opposition, it is the mobilisation of action through the spaces of intersection where new political paradigms for transport planning are created.
\end{abstract}

Key words: postpolitical, urban politics, transport, urban governance, Australia 


\section{Introduction}

A politics of mobility foregrounds the transition towards low carbon forms of urban transport (Urry, 2004). This transition is hindered by government prioritisation of freeway construction that continues in some North American and Australian cities (Boudreau et al, 2009; Stone \& Mees, 2010: Curtis \& Low, 2012; Walks, 2014). Entrenching the orthodoxy of road construction is a depoliticisation of transport decision making through the ascendency of new public management systems that rely on centralised executive decision making powers (McGuirk, 2005). In seeking to challenge the path dependent practice of road construction, citizen contestation against this dominant historical practice serves to politicise transport planning and its implementation.

Urban scholars have long argued that planning is a political and contested process (Wildavsky, 1973; Klosterman, 1978; Forester, 1989; Sandercock, 1995; Flyvbjerg, 1998); transport planning has a similar history of political contestation (Harcourt, 2007; Davison, 2004). But within the specific context of transport planning, Walks (2014) describes the tensions that transpire as a 'politics of automobility'. Urban transport planning is inherently political involving priority setting and investment decision making, which will ultimately serve some needs better than others. Yet the spaces where these political decisions are made are shielded from outside public interrogation where challenges could be lodged and bigger questions could be asked about the social distribution of benefits.

Limiting civic participation in transport decision making sets up a 'democratic deficit' (Marres, 2005) inhibiting citizens from challenging dominant urban transport discourses. New platforms are created elsewhere, but beyond the formal processes and institutions of the state. This is where the political is shifted, a phenomenon described within the urban studies literature as a postpolitical condition (Boland, 2014; Blühdorn, 2013; Bylund, 2012, Oosterlynck et al, 2010). The concept of the postpolitical can be traced to post foundational 
political theory and to the work of Mouffe (2005), Žižek (1999) and Rancière (1999) on the displacement of politics. In this work dissensus is central to a functioning democracy; it is the displacement of politics into locations beyond the state apparatus that is creating multiple sites of democratic practice (Marres, 2005). However as Bylund (2012) points out, the displacement of the rather informal (citizen driven) political from the formal (governmentled) postpolitical introduces an unhelpful binary. This binary fails to consider the multiple ways in which the two - government led interventionist decision making and citizen action intersect and where political and counter hegemonic pursuits may arise. This paper uses the terminology of binaries and intersections as a conceptual tool to engage with the postpolitical/political aspects of transport planning (Cloke et al, 2005). While binaries can provide a powerful description of difference, there is value in also understanding how these differences interact - and intersect - through a dialectical relationship creating opportunities for change (Harvey, 1996: 19). It is in these spaces of intersection, as Purcell (2013: 572) posits, that a process of "perpetual democratization” occurs.

Bridging the postpolitical and urban transport literatures invites a reconceptualisation of the politics of transport planning (and of strategic planning more generally) within a postpolitical context (Olesen, 2013: 298). Thinking about how a reconceptualization could transpire, the question guiding this paper is, in what ways can the political provide a platform for a redemocratisation of transport planning? To answer this question, the paper focuses on a single case study of a controversial urban transport infrastructure decision making process in Melbourne, Australia. The case is of wide, and arguably global, significance because it highlights a new escalation of postpolitical excess as well as the possibilities for citizen progressive counteraction. Although the controversial inner city road tunnel was deemed a 'done deal' by elected officials in the lead up to the November 2014 state election, the decision to expedite the signing of the project's contracts before the plebiscite was an 
extraordinary step by elected officials to remove the project from the formal political process. This only provoked a direct politicisation of the project. In addition, the government's decision to withhold the release of the business case for this project and its decision to accelerate contract signing for a public-private partnership delivery arrangement to mere weeks before a state election was met with significant tribulation and distress. Some residents were concerned about compulsory acquisition of their homes while others were troubled by the potential loss of significant urban parklands; long standing public transport advocacy groups feared this project would steer limited financial resources away from much needed public transport, and finally some residents were concerned that the democratic planning process that could build legitimacy around this project had been subverted. The latter concern forms the focus of this paper.

The sections that follow draw on the Melbourne case study to illustrate how affected and concerned citizens and community-based groups respond to the inherently political, yet not always democratic, aspects of setting transport investment priorities. The next section of this paper explores the tenuous link between transport infrastructure and citizen participation. Here the notion of a postpolitical decision making environment illustrates the implications that postpolitical governance frameworks have on broader notions of democratic process. From here I turn to a discussion on the binary created by a postpolitical and political framing before offering an illustrative example of how this binary introduces intersections from which a reimagining of an alternative transport future is possible. The paper concludes by discussing how the intersections that exist between the political and the postpolitical spaces enable a redemocratisation of transport planning.

\section{The tenuous link between transport infrastructure planning and participation}


Urban transport planning is weakly linked to progressive conceptions of participatory planning. Within urban scholarship, the spaces dedicated to theorising the role of citizen participation in transport implementation are limited (Molina Costa, 2014). This absence stands in stark contrast to the expansive body of theoretical and empirical research within the strategic planning literature that examines the relationship between citizen participation and policy decision making (Healey, 1997; Innes et al, 2010; Albrechts, 2012). Instead, the engagement of citizens at the implementation stage - the point in the planning process when infrastructure is delivered - is typically reduced to narrow consultation briefs and rarely associated with broader discussions about transport problems and possible solutions (Sturup, 2016). Under a neoliberal political regime, governments will seek to create a more certain investment environment to attract private sector participation. And in a post political context, governance aligns with a "managerial logic" that concentrates decisions into the hands of experts situated in non-state or quasi-state agencies (Swyngedouw, 2010: 225). Under these conditions the relationship between inclusive citizen participation, which is deliberative and supports transparency of decision making, and infrastructure delivery remains partial if existing at all.

But this is not to suggest that citizen participation at these latter stages in the transport planning process is entirely absent. Some planning jurisdictions impose legal requirements to undertake a form of citizen consultation. This may include a call for resident submissions, and in some planning jurisdictions opportunities to appeal decisions (as seen in Victoria and New South Wales, Australia and Ontario, Canada). In those jurisdictions that have embraced deliberative forms of engagement and despite these advances recent research has shown that innovation in participation - such as deliberative decision making seen in citizens juries have been embraced, but in very limited ways for the purpose of political experiment and grandstanding (Legacy et al, 2014), and to promote a kind of 'consensus politics' (Rancière, 
2000: 119). To establish an inclusive process of transport planning and implementation this would require repositioning citizens as key stakeholders towards a renewal of democracy (Bickerstaff and Walker, 2005), as well as recasting the relationship between infrastructure implementation and citizen participation.

Participation under a neoliberal political regime severely limits the democratic reach of participatory and deliberative planning. For instance, de Souza (2006: 334) argues that where participation exists formal processes of citizen participation provides an illustrative example of 'structural co-optation'. The political dimension that deliberation in participation introduces remains absent. Rancière (1999: 102) calls this condition postdemocracy defining it as, "the government practice and conceptual legitimization of a democracy after the demos, a democracy that has eliminated the appearance, miscount, and dispute of the people and is thereby reducible to the sole interplay of state mechanisms and combinations of social energies and interests”. The postpolitical represents that shift away from a purely social characterisation of politics to what Žižek (1999: 248) calls a "perverse mode of administering social affairs”. Yet Rancière (1999) and Mouffe (2005) challenge the provocation that politics can be eliminated; they describe politics as the passions and interests of individuals, and by eliminating politics is to support a kind of democracy that narrowly focuses on "reason, moderation and consensus” and evades conflict (Mouffe, 2005: 28).

The use of the word 'democracy' in this postpolitical neoliberal context is used in association with a form of governance that seeks to eliminate politics (Oosterlynck et al, 2010: 1581). Oosterlynck et al (2010: 1591) posits that under a postpolitical context, "politics is identified as ‘good governance', based on achieving a stakeholder-based negotiated consensus”. Hendriks (2014) describes 'good urban governance' as a set of underlying values and principles driving conduct, but separates it from what could be described as 'good urban politics'. Good urban governance provides the platform to which input legitimacy and output 
legitimacy for a proposed project can be exercised, but it fails to facilitate or provide an opportunity for political interventions to shape a new urban transport paradigm. Citizen participation as a component of urban democracy is restricted to serving the implementation of infrastructure and economic development (Sturup, 2010). Therefore bigger questions about what kind of urban transport infrastructure should be built, who will be served by it, and when and where should it be built could be addressed in policy and planning strategies but are rarely put forward by governments for discussion and rigorous evaluation (Legacy, 2014). But it is within these opaque structures of urban good governance, aligned with the postpolitical condition, which provokes an opening up of a new urban transport politics beyond the state if you will. As has been seen in the environmental sustainability movement (Blühdorn, 2013), the binary created between the postpolitical condition and the political invites a dialectic relationship that paradoxically acts to redemocratise and politicise urban transport planning. The new political game is being played out at these intersections.

\section{Political binaries}

The postpolitical condition (Rancière, 1999; Žižek, 1999; Mouffe, 2005) has reshaped the way the political is constituted in urban scholarship (Oosterlynck et al, 2010; Bylund, 2012; Metzger et al, 2015). However, as Davidson et al (2014: 4) posits, “Labelling cities 'postpolitical' risks treating depoliticisation as a condition that has been realized, rather than a tendency that has taken hold”. This fails to consider the dialectic nature of the political/postpolitical relationship. Critical appraisals of citizen engagement exercises that intercept a plan making effort have uncovered a consensual practice that does not present hard choices for careful open scrutiny (Albrechts, 2015; Purcell, 2009). In the context of urban transport, deliberative planning in such settings offers an insufficient democratic experience to residents seeking to transform urban transport decision making. When engagement does persist, these processes are characterised by bounded deliberative 
engagement that corrals citizens into formulaic objection settings that impose very strict and limiting procedural settings. It is in these settings where citizen opposition - often framed as 'NIMBY' opposition - are framed as non-rational and beyond the scope of the project and process for decision makers to consider.

Yet, it is the action taken by citizens beyond the state that is both redefining state-civil society interrelationships and forging an interactive setting that is driving socio-political innovation (Swyngedouw, 2005). Newman (2013: 9) argues that the postpolitical turn in urban planning is prompting new social movements embracing rather unique ways of "performing politics" but doing so in a manner that focuses efforts on the intersections created between the formal government rationalities of urban transport planning and the rationalities that exist beyond the state. Citizen opposition can prompt engaged residents and community-based groups to create informal spaces to devise transport strategies to counteract propositions by the government. There are many different theorisations that describe the act of opposing. These alternative planning spaces have come to be known by a range of different terminology. Insurgent planning, radical planning, grassroots planning and 'direct action' planning to name a few form a body of planning scholarship examining citizen activity made in response to and even in spite of the state (de Souza, 2006, Iveson, 2013). Considerably more informal and plural undertakings now represent the arenas where policy influence may arise. The postpolitical literature has used case studies to illustrate the displacement of the political to places outside of government (Mouffe, 2005). This creates a binary between the postpolitical mode of governing and the political reaction some communities have to closing the door completely; and when the door is open, the reaction directed at heavily stage managed consultation environments. Oosterlynck et al (2010: 1591) laments:

...by not recognising disagreement as the legitimate and proper basis of the political, cannot but fail to produce political solutions and results in an 
institutional and legal deadlock which undermines popular trust in politics while relegating key decisions to non-political economic or private actors.

Purcell (2013) describes the political as pluralistic consisting of a connected set of autonomous movements. This is more than another example of radical democracy or everyday pluralism (Laclau \& Mouffe, 1985). It is a movement that is also aware of the constraining effects of current institutions and is thus willing to seek transformational change through political struggle to reform and achieve structural change (e.g. introducing new funding regimes, etc). In the case study that follows, I examine the counterhegemonic movement that transpired with the announcement of a 6 kilometre inner city road tunnel project in Melbourne, Australia. Specific attention is given to exploring the political/postpolitical binary that formed in response to the announcement of the proposed project. I will also focus on the opposition that mounted at the intersection between the political and postpolitical and which forged political, institutional, cultural change within the deeply political spaces of transport planning.

\section{Research methods}

This study draws upon an ethnographic study of 15 community-based campaigners in Melbourne, Australia that engaged both with the government's formal consultation process and also actively pursued alternative forums to mobilise a broader effort to protest against a proposed 6 kilometre, inner city East West Link Road Tunnel. The timing of the ethnographic research deliberately focused upon a six-month period of public engagement between October 2013 to June 2014, which was marked by the release of the project's Comprehensive Impact Statement (CIS) and concluded with the approval of the proposed road tunnel in June 2014 by the Planning Minister. As an interested observer of the relationship between urban democracy and planning, I embedded myself within the campaign 
to stop the East West Link. I did so by attending street protests, community meetings and public forums as well as following twitter feeds and Facebook posts where I observed the strategies to protest against the projects and how the various groups coordinated their efforts with other groups. I also conducted interviews with 15 community campaigners. A cross section of campaigners was determined to capture different campaigning styles. There were those groups that embraced direct action forms of action such as on-street protests, as well as politically savvy strategists that worked to position the East West Link project on the political agenda in advance of the state election, and neighbourhood-based interest groups and broader-interest groups (e.g. pro-public transport groups). During this 6 month period of observation the 15 campaigners mounted a coordinated and collective effort to oppose this project. Semi-structured interviews with the campaigners were undertaken producing narratives about the campaigner's efforts to oppose the East West Link project. Interview questions prompted interviewees to speak candidly about their motivations to oppose the project, including reflections on their specific role and contribution to the broader anti- East West Link movement. The interview questions also invited campaigners to reflect upon their choice of strategies, and how these strategies helped (if at all) to forge relationships with other community groups to assert the political into transport infrastructure planning.

To capture the formal government engagement with affected residents, analysis was also undertaken of media releases, commercial media and policy documents. Also considered were participant observations from a 30-day public panel hearing where resident, local government and the authority responsible for the project - the Linking Melbourne Authority - discussed and debated their respective cases for and against the proposed project. Analysis from these observations and media stories provided an account of how the State Government interacted with and responded to opposition. The focus of this research was on the active citizens and community-based group’s engagement with a formal (postpolitical) CIS process 
and the (political) informal campaigns and protests that occurred beyond the government's formal process. It is important to note here that the positioning of the formal and informal engagement strategies as a political and postpolitical binary in some ways overly simplifies the relationship between the State and residents in opposition. To begin to understand the nuances of this relationship, I examine the dialectical relationship that this binary introduces and to reveal the ways in which transport politics is played out within a postpolitical context.

\section{Case Study: Melbourne’s East West Link}

Melbourne is a city that enjoys an expansive rail and tramway network, a product of the gold rush era of public expenditure. But in the past six decades a lack of investment in urban public transport has not kept pace with a growing urban population that is forecasted to reach 8 million inhabitants by 2050 (Victorian Government, 2014). In 2010, following decades of disinvestment, a new government was elected in the State of Victoria on an election platform to build public transport. Labor's time in power (between 1999 to 2010) resulted in no substantial expansion in public transport infrastructure within the metropolis. Instead the Labor government successfully produced five transport plans over an eleven year period but it was their inability to implement those plans which commentators prescribed as the primary factor that led to their election defeat in 2010 (Davidson, 2010).

In the lead up to the 2010 election, the opposition party pledged to 'Fix the problems. Build the future' (Austin, 2010). The Liberal-National Coalition was elected to government on November 27, 2010 with public transport forming its key platform issue. Its centrepiece was a $\$ 1.55$ billion transport policy pledging improved train, tram and bus services and the construction of rail links to Victoria's two airports. A newly formed independent Public Transport Authority would also oversee the development of regional rail links, a crosscountry passenger rail route, and new stations in the middle suburbs (Austin, 2010). 
Following the election, surfacing to the top of this project priority list was an inner city East West Link road tunnel. In December 2012 the East West Link was declared a major transport project of state significance under the Major Transport Projects Facilitation Act 2009. A year later, a Bill was introduced into State Parliament in June 2013 to amend this Act to "reduc[e] procedural delays and red tape” for all large urban transport projects, including the East West Link (Parliament of Victoria, 2013). At the second reading of the Bill, Opposition Planning Minister Brian Tee stated his concerns arguing that the proposed amendment would “exclude[] local communities from the process" and give "the minister power to .... decide which matters will be considered at a public hearing. The minister, not the public, will decide what is important” (Tee, 2013). What Tee did not note in his speech to the State Parliament in September 2013 was that the Minister for Planning would also be given “Overarching approval decision” for this project (DTPLI, 2013: 11).

The elevation of the East West Link as a major transport priority in 2012 occurred in the absence of community engagement, and was quickly positioned in the wider media and political discourse as a 'done deal'. Initially, a unilateral decision by the state government positioned the road tunnel as the state government's number one transport priority. This positioning was further crystallised when the newly elected federal government committed $\$ 1.5$ billion of federal money exclusively to fund the controversial inner city road tunnel project (Wright, 2014). With this investment pledge in place, and following the release of the state and federal budgets in early 2014, both the Australian government and the state government firmly committed to building this road above all other alternative public transport projects in Victoria.

\section{Subverting the political in transport planning}


In July 2010, Victoria’s Minister for Roads established the statutory agency the Linking Melbourne Authority (LMA) under the Transport Integration Act 2010 to manage complex road projects on behalf of the State (LMA, 2014). The state government announced that, through a process called a Comprehensive Impact Statement, it would examine the anticipatory impacts from the proposed project. The process involved a public exhibition of the CIS report, a public submission process and a thirty-day panel hearing (LMA, 2014). In May 2013, the Planning Minister published the scoping directions for the CIS (DTPLI, 2013: 9). At this time, affected residents and the broader public were invited through local newspaper and government websites to prepare written submissions to a Minister appointed Independent Assessment Committee (IAC). The IAC would then respond directly to citizen concerns as they related to a predetermined set of evaluation objectives and a 'reference design' (DPTLI, 2013: 12); the former was prepared by the Minister and the latter prepared by the LMA (The Act, 2009: 26; DTPLI, 2013: 9 -10). As was made clear in the CIS statement, firms tendering for the project could “offer variations to its design or route alignment that deliver better value for money or that incorporate innovative approaches to design, technology or operations that have not been considered specifically as part of the assessment of the Reference Project” (DTPLI, 2013: 11). Over 1,500 individual submissions were lodged in that period from across metropolitan Melbourne and the state of Victoria. Following the submission period, a public hearing was held between March and April 2014. Submitters, including special interest groups (including local government and communitybased organisations) as well as individuals were invited to present their concerns to the IAC.

Following public and media scrutiny directed at the state government for refusing to release the Business Case for the project, citizen opposition leading into the CIS process was already fierce. Thus, when the state government announced the two stage CIS process in October 2013 at the same time as a call to tender for the construction and operation of the tunnel 
project, cynicism was directed at the government's formal consultation process. There was a degradation of trust, as indicated in the following CIS submission:

The CIS assumes that effective mitigation of impacts will be achieved because of effective community consultation and engagement and yet the community consultation on this project to date has been very unsatisfactory. Where information should have been provided in a meaningful way, far too often we have been given promotional material. The “detailed project design animation” on the LMA website for example is hardly that and is basically a sales pitch for the project lacking some important details. Hardly surprising perhaps but there is little else, and it is not a good basis for building trust in any future consultations (Residents Against the Tunnel CIS Public Submission, 2013: 3).

The process was linear and top-down and did not invite an interactive or reflexive engagement between citizens, project proponents and the multiple tiers of government, which could have enabled scrutiny of the project's scope as well as finer details revealed as the project's design matured. Instead, the CIS process was designed in a manner that subverted the political, sidelined contestation and disavowed the engaged citizen as a political subject (Rancière, 1999) worthy of and able to engage thoughtfully with the project selection process.

The announcement to commit to a major road project in their first term of government occurred in parallel to an 18-month extensive public engagement process to produce a new planning strategy for the state. October 2013 - which marked the start of the CIS process also marked the release of the draft planning strategy. This plan proposed a number of other priority transport projects for the state including a number of large public transport projects. Examination of the 18-month plan making process revealed that the EWL project was not put forward to the citizens of Victoria. This engagement platform offered few opportunities to 
citizens to question the efficacy of the project or consider if the public dollars could be spent elsewhere.

At the end of 2013, and following the decline of the automotive industry in the state of Victoria the proposed road tunnel was positioned by the state government as part of a broader economic crisis management strategy (Lucas et al, 2014) - the construction of the tunnel would produce a forecasted 3,500 construction jobs and would help to boost the local economy (ABC News, 2014). A move to fast-track the delivery of the road tunnel under the Act 2009 was initiated by state politicians to deliver key infrastructure for Victorians. However, the move to push the signing of the contracts to just weeks before the November state election was widely held by civil and professional interest groups to be an assault on the democratic process (see below). There was a growing discord that the political will to see the East West Link to fruition was effectively working to suppress opportunities to openly discuss and debate the merits of the project.

\section{Reaction, action and intersections}

Positioning the East West Link tunnel as the State’s top transport priority, prompted several groups, including political, professional and civil bodies to emerge in opposition to the East West Link. The government's top down intervention to position the East West Link as the state's number one transport and infrastructure priority occurred in a vacuum of critical debate over transport projects in the state. One campaigner expressed a concern about a growing vacuum of honest and informed scrutiny directed at the government over their transport decisions. Pointing fingers at a lack of critical engagement on the part of academics, the major opposition party, and senior government transport bureaucrats; this perceived absence of critical debate catalysed some citizens to play a more active and political role:

I think maybe it's up to the community now. We are not going to get it from the 
Government; politicians follow they don't lead. We're not going to get it from the Department because the Department is only going to do what the Government tells them. We can't get a lot of academics because one way or another they are financially compromised too through grants. But someone has to be able to stand up (Interviewee 6)

Long standing transport advocacy groups such as the Public Transport Users Association, local government councils located within the inner city and even smaller neighbourhood associations took it upon themselves to change the rhetoric around transport in the state. Their focus was on presenting transport infrastructure planning as a grassroots political issue. Critically, their efforts would be directed at (1) shaping the Opposition Party’s transport policy and, (2) positioning the East West Link as a key election issue in the forthcoming state election. Mounting a grassroots campaign, long standing public transport advocacy groups organised activities ranging from door-knocking and letter-writing campaigns, public rallies and street protests, holding public forums and conducting surveys and polls in marginal seats. Other groups adopted direct-action strategies aiming to stop preliminary drilling at sites along the project's corridor, while other resident groups took to writing letters into the state newspapers and sought expert and legal advice on how to stop the project.

One tactic the community pursued was to delay the signing of the contracts until after the election. Doing so would position the project as an election issue:

The most realistic thing for us and our primary aim is to delay the signing of the contracts. The Premier's intention is to sign the contract 6-8 weeks before the election and we think that is fundamentally undemocratic and it should go to an election. And if it goes to an election then let Victorians decide. Everyone is impacted by this, whether you live in Ballarat or Ararat or Gippsland you are 
impacted by it and we think it should be an election issue. This is really starting to come out now. (Interviewee 12)

Another strategy considered by residents and public transport advocacy groups was to establish a community-wide coalition called the Victorian Integrated Transport Alliance (VITAL). As an observer at that first meeting, it was noted that a narrow focus on organisational details quickly shifted focus away from mobilising action to both oppose the project and to delay the signing of the contracts. Following this failed attempt to establish a coalition, one of the long standing public transport advocacy groups mounted the Public Transport Not Traffic (PTNT) campaign, which quickly became the umbrella campaign from which all other groups sought to align. Interest in a non-hierarchical community-based structure was superseded by a more top down and aggressive coalition form that could actively engage in two primary ways: by responding to frequent and mostly unpredictable government announcements and timelines for community engagement and contract signing, and by providing strong leadership that could strategically oppose the East West Link project, without co-opting groups into a unified structure. One campaigner interviewed for this research remarked that the PTNT campaign offered leadership and direction to respond to very tight timeframes available to influence policy and outcomes, and also allowed groups to remain autonomous to pursue their own lobbying efforts.

Public Transport Not Traffic. That group is now moving very quickly and it’s a completely different model of organisation. It's not consensus based. It's a loose coalition in the sense that it includes 30 or so groups from across Melbourne - and really truly from across Melbourne - that support what PTNT stands for. (Interviewee 14)

The PTNT campaign represents a significant shift away from consensus politics that have 
come to be associated with neoliberal governance frameworks. More specifically, the campaign reveals cracks between the postpolitical/political binary. For example, the campaign departs from a common model of citizen, grassroots activism that sometimes evolves into a network of groups who come to share a similar objective - be that a more sustainable future or a shared pursuit of the common good. In the case of the PTNT, each group could remain autonomous within this loose structure, but still collectively engage in a broader political movement. In most cases the strategies both associated with the campaign and with the individual groups were necessarily reactive to effectively respond to government decisions and media releases. Several groups felt that they were forced into this reactive position with little time to mobilise a proper fight. One campaigner described the reasons for such a reactive disposition:

We're operating on a timeline and we're operating to an election not because we want to but because that's the agenda that [the Premier] set. He said he wants to get all this up and running before the State election, well you're setting the timeline then, we're going to play those cards. Whatever cards we have we'll play, because of the tight timeline you're giving us (Interviewee 16).

Community-based groups launched reactionary campaigns to the media commentary that sometimes painted these inner city residents and groups as "The ratbag gang of unionists, unwashed hippies, NIMBY greenies, bellicose socialists, confused pensioners and progresshating layabouts” (Panahi, 2013). In response, campaigners found it critical to maintain morale and confidence that change is possible in the context of 'done deal' politics. The interview data revealed a strong sense of purpose amongst the groups to contribute. One campaigner shared:

We are making everyone aware of the impact on [our community] with calls to 
action. And then participating with other community groups has been a big part of what we've done. We have been an information channel for some stuff. (Interviewee 7)

There is also evidence of self-awareness exhibited by campaigners that their efforts against the tunnel is perceived by some as an inner city NIMBY battle. Transcending beyond the NIMBY framing of an inner city elite preserving their existing liveability, campaigners aimed to transform the discussion to appeal to residents and groups living beyond the immediately affected corridor. This led some inner city groups to adjust their campaign strategies accordingly to form broader, spatially diverse, anti-East West Link and pro-public transport alternative movements.

I don't even want to bother in the Collingwood/Fitzroy space because it’s literally flooded. The people in that area are well informed, they are already campaigning and that's great....Instead we really need to go to the outer suburbs and have more conversations with them. These are the people who actually have shit public transport. Collingwood and Fitzroy, public transport is alright, they could do with a train line, but they're OK. (Interviewee 16)

The sentiment expressed from this interviewee reveals the nuance of the political/postpolitical binary. There is a spatial dimension associated with the binary as illustrated by the case that reveals subjectivity linked with the politicisation of the transport issue. For many of the long standing public transport advocacy groups implicated in this movement campaigns were focused on inviting the broader community to imagine an alternative future. Examining the strategies employed by these 15 campaigners, their individual and collective efforts were undertaken in a pragmatic way. Citizens and established community-based groups organised public panels and workshops, and commissioned transport planning academics from the local 
universities to share their expert knowledge. What is also evident by the breadth and content presented across the range of campaigns and events is a broad engagement with the transport 'problem' that is affecting metropolitan Melbourne. Groups also gave their attention to demonstrating how funding the East West Link tunnel would result in other public transport projects not being funded. Those groups advocating 'a positive alternative' to the controversial East West Link project remain engaged in the anti-East West Link movement. However, these groups sought to reposition public transport as the unfunded number two priority to the funded priority number one project.

\section{Intersections and interceptions}

The Government led CIS process framed the proposed road tunnel as a 'done deal'. This meant that the government-designed CIS process would focus narrowly upon anticipatory negative effects and their management. Opponents of this project mobilised grassroots campaigns to slow down the signing of the contracts as it was hoped that by preventing the contracts from being signed before the election, the East West Link tunnel would emerge as a primary election issue opening this project to public scrutiny. At the start of this study the main opposition party - the Labor Government - stated that they would not proceed with the project if contracts were not signed before the election. It was in the context of this statement that slowing contract signing emerged as the primary goal for citizens and if successful, their attention would then turn to the election. One campaigner commented upon the party-political nature of the East West Link project siting the need to engage with the upcoming election cycle:

Realistically it will be very difficult...a political decision has been made, it’s a political issue. The only way we are going to change it is politically. I don't think we are going to change [the Premier's] mind. He’s locked in, he locked himself in 
a long time ago and he continues to lock himself in. So he’s backed into a corner and so he isn’t going to suddenly do a mia culpa and suddenly say “what a mistake, I've realised this is a disaster and I'm going to pull out of it” It's not going to happen (Interviewee 12).

Slowing down the signing of the contracts until after the state election meant that for some groups and individuals their primary focus was on engaging with the CIS. The selection of an Independent Assessment Committee offered initial hope to residents and those communitybased groups who believed that if enough compelling evidence was presented, the project as it was initially conceived would need to be rescoped, which would warrant a review of the CIS brief, and therefore delay the contract signing. A former Labor Government advisor and long-time transport advocate, proved to be a valuable resource to the community groups during the CIS process. Drawing from his experience in government he believed that the process was so tightly comprised to meet the looming deadline that any suggestion that the project reference should be reconsidered, the project would be inevitably delayed:

I don't think it's wasted time ...If all the community groups did [was advocate for no East West Link tunnel] they wouldn’t be likely to get a result. I mean, this project will fall over if it stumbles. If it's held up for three months it will never go ahead. So the government is relying on momentum and momentum solely and they have locked themselves into an insane timeframe of having the contracts signed by October, which I don’t think is physically possible, but I guess we'll see (Interviewee 13).

Cynicism around this process however propelled some groups to consider a formal legal challenge against the government directed at the CIS process. Two inner city local councils would also lead legal challenges. Other groups chose to focus on the chance that the project 
would form a key election issue in the lead up to the 2014 November State election. This included placing significant pressure onto the opposition party to oppose the road tunnel and commit to tearing up the contracts (once they are signed). A position such as this, taken up by the primary opposition party, would position the East West Link as an election issue. Other groups sought support to oppose this project by engaging in a debate about the relationship between infrastructure and job creation. Their proposal was not anti-development or antineoliberalism. Rather, campaigners were prepared to engage in a debate about alternative avenues to promote job growth and economic stimulus. Policy and politically savvy campaigners - people that have held senior advisory positions in government, or are seasoned campaigners - prepared economic arguments to oppose the project. In one particular instance, effort was made to show how the construction and long term operation of an urban train line offered higher economic rewards (including jobs creation) than a road. Analysing US federal spending into transport the Public Transport Not Traffic campaign reported on their website that: "investment in public transportation produced almost twice as many jobs per dollar as investments in roads. Every one billion dollars (USD) spent on public transportation produced 19,299 jobs, compared with only 10,493 jobs if the same was spent on highway road works” (PTNT, 2014).

Following months of pressure, in September, two months before the state election, the opposition party declared that if signed before the election, they would destroy the contracts upon being elected if the court case lodged by the inner city local governments ruled in favour of these local governments. It was at this point that the East West Link project was no longer framed as a done deal. Rather, the project could now be contested at the ballot box. Indeed, on 29 November 2014, the Labor party was elected into government with a commanding majority and the East West Link tunnel was removed from the state transport agenda to much fanfare from the community campaigners. 


\section{Conclusions}

This paper examined the binaries that are introduced when postpolitical governance provokes political contestation from beyond the state and the intersections this binary forges. Bylund (2012) suggests that framing recent political contestation through a postpolitical/political binary fails to consider the dialectic potential of this contested landscape to both transform the transport planning agenda as well as transform how that agenda is set. The ascendency of neoliberal governance settings within transport planning and infrastructure implementation more broadly has allowed consensus driven politics to continue to nurture a culture of automobility (Walks, 2014). Without a public discussion that challenges the positioning of the auomobility discourse, a paradigm shift will be difficult to achieve. The binary set up by the postpolitical/political does not go far enough as a theoretical framework to offer a basis to inspire long term institutional, political and cultural change.

The Melbourne case study offers an extreme case (Flyvbjerg, 2006) of the kind of colonisation of the decision making space that restricts debate and avoids conflict. In the case of the East West Link road tunnel, both the Australian and Victorian Governments embraced a postpolitical positioning. This is evidenced by the State Government's efforts to restrict public discussion and scrutiny of the East West Link tunnel project by keeping the business case confidential, fast-tracking the signing of the contracts, and avoiding a public discussion around transport alternatives. Few efforts were taken to actually construct a process where public legitimacy for this project could be sought (Oosterlynck et al, 2010). Instead, the decision to avoid a discussion around alternative ways to address the transport problems facing Melbourne, as well as offer a clear articulation of what those challenges actually are, aimed to evade (albeit unsuccessfully) any challenges to the dominant discourses around automobility. In this case, the postpolitical position embraced by the government resulted in a decision to avoid public scrutiny and contestation of this road project. Such a decision was 
inherently a political one, and as a result of advocacy groups engaging at the intersections of the postpolitical/political binary, their actions repoliticised the political action taken by the government. The decision to avoid public scrutiny and contestation of this road project was inherently a political action (by government asserting an automobile vision of mobility), which was ultimately addressed in a political event: the state election.

What can be learned from the Melbourne case study? On a practical level, despite all efforts to depoliticise infrastructure prioritisation, decision makers still confront a political landscape of resistance and dissent, be that from the development industry, interest groups and/or citizens. It is not possible to separate the politics from infrastructure implementation, nor is it desirable. New urban governance settings that respond to the politics are needed. These settings would invite debate and public deliberation and would not disavow this process of its politics. In cities like Melbourne, the absence of formal deliberation and democracy at this critical stage in planning forces concerned and politically engaged citizens and community groups to create their own informal deliberative and democratic spaces - whether they are public forums where knowledge and information can be exchanged, preparing economic arguments in favour of alternative transport projects, or appearing on local television and radio programs to present the case against the East West Link. The politicisation of transport to the spaces beyond the formal government processes (e.g. the CIS two stage process) is shaping a redemocratisation of transport planning that is occurring at the intersections between postpolitical formal government processes and political grassroots activism.

At a theoretical level, as Inch (2012) has argued recently, the implementation stage of planning is the point in the planning process when negative impacts are more clearly known and when citizens are most likely to actively engage agonistically. But unlike the NIMBY conflicts, citizens may also embark at this stage in planning through their own directed process of deliberation and coalition forming to counter hegemonic policy settings. 
Perversely, the postpolitical era in urban policy has reconstituted democratic practice. The postpolitical turn has not rendered urban transport planning non-political, but rather the opposite; the political has emerged elsewhere and is forming a redemocratisation of city making through emergent accountability and deliberative spheres of engagement, led by citizens. The case of citizen opposition to the proposed road tunnel in Melbourne illustrates not that transport planning is political, but how this politics is played out. It illustrates what Marres (2005: 135) describes as the "modifications of democratic spaces” challenging the view that all politics is to occur within the formal spaces of planning. Drawing inspiration from the work of Dewey (1927[2012]) on the role politics plays in constituting the public, Marres (2005) and others writing in the space of science and technology studies such as Whatmore and Mandstrom (2011) and Callon et al (2009) argue that the displacement of politics supports the creation of a political (or rather a dialectical) democracy and an active public that can continue to engage with critical urban issues; in the case of Melbourne, that issue was alternative transport priorities. The extent to which citizens influence decisions, in part depends on their actions beyond the formal state processes. In these informal spaces, citizen action groups are seeking ways to not only dictate an alternative urban transport policy agenda, they are also advocating for ways to reinstate democratic practice into planning by reasserting themselves into decisions that affect their lives. For some, there is a need to 'work[] together better' (Brownhill \& Parker, 2010: 281) across all actors groups to both change the urban policy debate and to inspire urban politics that speaks to the reality of climate change and oil vulnerability; and not be constrained by the limits of the institutional and postpolitical dispositions embraced by some governments. 


\section{References}

ABC News (2014) PM committed to second phase of East West Link as job creation initiative, ABC News, Canberra 14 May, 2014, accessed 16 December, http://www.abc.net.au/news/2014-03-14/pm-committed-to-east-west-link-as-job-creationinitiative/5320636

Albrechts L (2015) Ingredients for a more radical strategic spatial planning. Environment and Planning B: Planning and Design 42: 000-000.

Albrechts L (2012) Reframing strategic spatial planning by using a coproduction perspective. Planning Theory. 0(0): 1-18.

Austin P (2010) Labor’s forward focus designed to make voters forget failures, Sydney Morning Herald, accessed 15 December, http://www.smh.com.au/federal-politics/politicalopinion/labors-forward-focus-designed-to-make-voters-forget-failures-20101103-17dz5.html

Bickerstaff K and Walker G (2005) Shared visions, unholy alliances: power, governance and deliberative processes in local transport planning. Urban Studies 42(12): 2123-44.

Blühdorn I (2013) The governance of unsustainability: ecology and democracy after the postdemocratic turn. Environmental Politics 22(1): 16-36.

Boland P (2014) The relationship between spatial planning and economic competitiveness: the 'path to economic nirvana' or a 'dangerous obsession'?. Environment and Planning A 46: 770-87.

Boudreau J-A, Keil R and Young D (2009) Changing Toronto: Governing urban neoliberalism. University of Toronto Press, Toronto. 
Brownhill S and Parker G (2010) Why bother with good works? The relevance of public participation(s) in planning in a post-collaborative era'. Planning Practice and Research 25(3): 275-82.

Bylund J (2012) Postpolitical correctness? Planning Theory 11(3): 319-27.

Callon, M, Lascoumes, P \& Barthe, Y (2009) Acting in an uncertain world: An essay on technical democracy. Cambridge: MIT Press.

Cloke, P \& Johnston, R (2005) 'Deconstructing human geography's binaries', in P Cloke \& R Johnston (eds), Spaces of geographical thought: Deconstructing human geography's binaries, London: SAGE Publications, p. 1-20.

Curtis C and Low N (2012) Institutional barriers to sustainable transport. Surrey: Ashgate Davison G (2004) Car Wars: How the Car Won our Hearts and Conquered our Cities, Crows Nest: Allen and Unwin.

Davidson K (2010) Labor’s loss is explained by the rail politics. Sydney Morning Herald, 30 November 2010, http://www.smh.com.au/federal-politics/political-opinion/labors-loss-isexplained-by-the-rail-politic-20101129-18dwp.html

Davidson, M and Iveson, K (2014) Recovering the politics of the city: From the 'post-political city' to a 'method of equality' for critical geography. Progress in Human Geography: 1-17.

de Souza ML (2006) Together with the state, despite the state, against the state: Social movements as 'critical urban planning' agents. City 10(3): 327-42.

Dewey, J (1927 [2012]) The public and its problems: an essay in political inquiry. Pennsylvania: Penn State Press. 
DTPLI (2013) East West Link (Eastern Section) - Comprehensive Impact Statement', Department of Transport, Planning and Local Infrastructure, State Government of Victoria, Australia

Flyvbjerg B (2006) Five Misunderstandings About Case-Study Research. Qualitative Inquiry, 12(2): 219-45.

Flyvbjerg, B (1998) Rationality and Power: Democracy in Practice. Chicago: The University of Chicago Press.

Forester, J (1989) Planning in the Face of Power. Berkeley: University of California Press.Harcourt M, Cameron K and Rossiter S (2007) City Making in Paradise: Nine Decisions that Saved Vancouver. Vancouver: Douglas and MacIntyre.

Harvey, D (1996) Justice, Nature and the Geography of Difference. Cornwall: Blackwell Publishers.

Healey P (1997) Collaborative Planning: Shaping Places in Fragmented Societies. London: MacMillan Press Ltd.

Hendriks F (2014) Understanding Good Urban Governance: Essentials, shifts, and values. Urban Affairs Review 50(4): 553-76.

Inch A (2012) Creating 'a generation of NIMBYs'? Interpreting the role of the state in managing the politics of urban development. Environment and Planning C: Government and Policy 30: 520-35.

Innes JE and Booher DE (2010) Planning with complexity: An introduction to collaborative rationality for public policy. New York: Routledge. 
Iveson K (2013) Building a city for 'The People': The politics of alliance-building in the Sydney Green Ban Movement. Antipode 00(0): 1-22.

Klosterman, R E (1978) 'Foundations for normative planning', Journal of the American Institute of Planners 44(1): 37-46.

Laclau E and Mouffe C (1985) Hegemony and Socialist Strategy: Towards a radical democratic politics. London: Verso.

Legacy C (2014) Public plan-making: A deliberative approach. In Gleeson B and Beza B (eds) The Public City: Essays in honour of Paul Mees. Melbourne: Melbourne University Press, pp. 74-88.

Legacy, C, Curtis, C and Neuman, M (2014) Adapting the deliberative democracy 'template' for planning practice. Town Planning Review. 85(3): 319-40.

LMA (2014) About Us, Linking Melbourne Authority, Melbourne, Australia, accessed December 13, http://www.linkingmelbourne.vic.gov.au/about-us

Lucas C, and Hawthorne M (2014) Road to recession: end of car industry may cost 50,000 jobs. The Age, February 11, 2014, accessed 18 Dec http://www.smh.com.au/federalpolitics/political-news/road-to-recession-end-of-car-industry-may-cost-50000-jobs20140210-32d3g.html

Marres, NS (2005) 'No Issue, No Public: Democratic deficits after the displacement of politics', PhD thesis, University of Amsterdam.

McGuirk P (2005) Neoliberalist Planning? Re-thinking and Re-casting Sydney's Metropolitan Planning. Geographical Research 43(1): 59-70. 
Metzger, J, Allmendinger, P \& Oosterlynck, S (eds) (2015) Planning Against the Political:

Democratic deficits in European territorial governance. New York: Routledge.

Molina Costa P (2014) From plan to reality: Implementing a community vision in Jackson Square, Boston. Planning Theory and Practice 15(3): 293-310.

Mouffe C (2005) On the Political. London: Routledge.

Newman J (2013) Governing the present: activism, neoliberalism, and the problem of power and consent. Critical Policy Studies 8(2): 133-147.

Olesen, K (2013) 'The neoliberalisation of strategic spatial planning' Planning Theory. 13(3): 288-303.

Oosterlynck S and Swyngedouw E (2010) Noise reduction: the postpolitical quandary of night flights at Brussels airport. Environment and Planning A 42: 1577-1594.

Panahi R (2013) Protesters’ arrogance undermines their cause over East West Link. The Herald Sun 11 November 2013, accessed 16 December 2014 http://www.heraldsun.com.au/news/opinion/protesters-arrogance-undermines-their-causeover-east-west-link/story-fni0fhh1-1226756866171

Parliament of Victoria (2013) Major Transport Projects Facilitation Amendment (East West Link and Other Projects) Bill 2013. Victorian Bills, http://www.austlii.edu.au/au/legis/vic/bill/mtpfawlaopb2013821/

PTNT (2014) Does public transport infrastructure create more jobs than roads? Public Transport Not Traffic website, Melbourne, accessed 16 December 2014, http://www.publictransportnottraffic.org/jobs 
Purcell M (2009) Hegemony and Difference in Political Movements: Articulating networks of equivalence. New Political Science 31(3): 291-317.

Purcell M (2013) To inhabit well: Counterhegemonic movements and the right to the city. Urban Geography 34(4): 560-74.

Rancière, J (1999) Dis-agreement: Politics and Philosophy. London: University of Minnesota Press.

Rancière J (2000) Dissenting Words. A conversation with Jacques Ranciere (with Davide Panagia). Diacritics 30(2): 113-26.

Residents Against the Tunnel (2013) Comprehensive Impact Statement, Residents Against the Tunnel (RAT) Response. Submission to Comprehensive Impact Statement review process, Melbourne, Australia

Sandercock, L (1995) 'Voices from the Borderlands: A meditation on a metaphor', Journal of Planning Education and Research 14(2): 77-88.

Stone J and Mees P (2010) Planning public transport networks in the post-petroleum era. Australian Planner 47(4): 263-71.

Sturup S (2016) The problem/solution nexus and its effects on public consultation. In Leshinsky R and Legacy C (eds) Instruments of Planning: Tensions and challenges for more equitable and sustainable cities. New York: Routledge.

Sturup S (2010) Managing mentalities of mega projects: The art of government of mega urban transport projects. $\mathrm{PhD}$ thesis, The University of Melbourne: Melbourne.

Swyngedouw E (2005) Governance innovation and the citizen: The Janus Face of Governance-beyond-the-State. Urban Studies 42(11): 1991-2006. 
Swyngedouw E (2010) Apocalypse Forever?: Post-political populism and the spectre of climate change. Theory, Culture \& Society 27(2-3): 213-32.

Tee B (2013) Major Transport Projects Facilitation Amendment (East West Link and Other Projects) Bill 2013 - Second Reading). Parliament of Victoria, 3 September 2013

The Act (2009) Major Transport Projects Facilitation Act 2009, No. 56 of 2009, Government of Victoria, Melbourne, Australia

Urry, J (2004) The 'system' of automobility. Theory, Culture \& Society 21(4-5): 25-39.

Victorian Government (2014) Plan Melbourne: metropolitan planning strategy, Department of Transport, Planning and Local Infrastructure, Melbourne.

Walks A (2014) Stopping the 'War on the Car': Neoliberalism, Fordism, and the Politics of Automobility in Toronto. Mobilities: 1-21.

Whatmore, SJ \& Landstrom, C (011), 'Flood apprentices: An exercise in making things public', Economy and Society 40(4): 582-610.

Wildavsky, A (1973) 'In Planning is Everything, Maybe it's Nothing'. Policy Sciences 4: 12753.

Wright J (2014) Tony Abbott says he doesn’t need to see the east-west link’s full business case. The Age, 27 September 2013, accessed Dec 18 http://www.theage.com.au/victoria/tonyabbott-says-he-doesnt-need-to-see-the-eastwest-links-full-business-case-20130927-

$\underline{\text { 2uih8.html }}$

Žižek, S (1999), The ticklish subject: The absent centre of political ontology, Verso, New York. 